\title{
Przebieg i zawieszanie postępowań administracyjnych prowadzonych wobec beneficjentów środków przeznaczonych na realizację programów finansowanych z udziałem środków europejskich w dobie COVID-19 w Polsce
}

The operation of public administration in Poland during Covid-19 - rules for suspending administrative proceedings regarding receivables due to the return of funds allocated for the implementation of programs financed with European funds

Ход и приостановление административного производства, проводимого

в отношении бенефициаров средств, предназначенных для реализации программ, финансируемых с участием европейских фондов в эпоху COVID-19

в Польше

\author{
ALEKSANDRA KLICH \\ Dr, Uniwersytet Szczeciński \\ e-mail: aleksandra.klich@usz.edu.pl, https://orcid.org/0000-0002-2931-712X
}

\begin{abstract}
Streszczenie: W opracowaniu zwrócono uwagę na to, że sytuacja związana z COVID-19 dotknęła także beneficjentów funduszy europejskich. W perspektywie finansowej UE 2014-2020 w Polsce funkcjonują liczne krajowe programy operacyjne, $w$ tym. m.in. 16 regionalnych programów operacyjnych realizowanych na poziomie województw (RPO). Celem opracowania jest próba ustalenia dopuszczalnego zakresu funkcjonowania organów administracji publicznej prowadzących w czasie COVID-19 tzw. postępowania zwrotowe wobec beneficjentów środków unijnych, w szczególności w zakresie możliwości ich zawieszania lub wydłużania przewidzianych przepisami prawa terminów na dokonanie określonych czynności. Zwrócono uwagę na dynamizm prac ustawodawcy w tym zakresie, w szczególności analizując postanowienia COVID-19U (tekst jednolity: Dz. U. z 2020 r. poz. 1842) z postanowieniami tzw. specustawy funduszowej (Dz. U. z 2020 r. poz. 694), która miała zapewnić płynną realizację i rozliczanie projektów. Rozważania teoretycznoprawne oparto na doświadczeniu wynikającym ze współpracy z IZ RPO oraz z danymi pochodzącymi z 8 województw realizujących RPO.
\end{abstract}

Słowa kluczowe: postępowanie administracyjne, zawieszenie postępowania, środki unijne, regionalny program operacyjny, COVID-19

Summary: In the article, the author points out that the COVID-19 situation has affected the beneficiaries of European funds. In the EU financial perspective 2014-2020, there are numerous national operational programs in Poland, including e.g. 16 regional operational programs implemented at the voivodeship level (ROP). The aim of the study is an attempt to determine the permissible scope of the operating capacity of public administration bodies conducting the so-called COVID-19 return proceedings against beneficiaries of EU funds, in particular regards to the possibility of suspending or extending the time limits provided for by law for performing specific activities. The author pays attention to the dynamism of the legislator's work in this regard, in particular by analysing the provisions of the COVID-19 Act (Journal of Laws of 2020, item 1842) with the provisions of the so-called special fund act (Journal of Laws 2020, item 694), which was meant to ensure smooth implementation and settlement of projects. The author of the theoretical and legal considerations based the results from the experiences while cooperating with the ROP managing authority and data from 8 voivodeships implementing ROPs.

Key words: administrative proceedings, suspension of proceedings, EU funds, regional operational program, COVID-19 
Резюме: В статье обращается внимание на то, что ситуация, связанная с COVID-19, отразилась и на бенефициарах европейских фондов. В финансовой перспективе ЕС 2014-2020 в Польше существует множество национальных оперативных программ, включая, среди прочего, 16 региональных оперативных программ, реализуемых на уровне воеводств (РОП). Целью исследования является попытка определить допустимые рамки функционирования органов государственного управления, осуществляющих во время COVID-19 так называемые процедуры возврата средств в отношении бенефициаров фондов EC, в частности, в отношении возможности их приостановления или продления сроков, установленных законом для выполнения определенных действий. Было обращено внимание на динамику работы законодателя в этом направлении, в частности, путем анализа положений COVID-19U (консолидированный текст: Законодательный вестник 2020 года, статья 1842) с положениями так называемого Специального закона по фондам (Законодательный вестник 2020 года, статья 694), которая должна была обеспечить беспрепятственную реализацию и расчет проектов. Теоретические и правовые соображения были основаны на опыте сотрудничества с управлением РОП и данных 8 воеводств, внедряющих РОП.

Ключевые слова: административное производство, приостановление производства, фонды ЕС, региональная оперативная программа, COVID-19

\section{Wstęp}

Wybuch pandemii COVID-19 i jej międzynarodowy charakter skutkuje nadwyrężeniem niemalże każdego obszaru życia codziennego, co wyraża się nie tylko w zakłóceniu prawidłowego funkcjonowania gospodarki, sektora publicznego, systemów opieki zdrowotnej czy edukacji. Jej skutki stanowią ogromne wyzwanie dla rządów na całym świecie, co wyraża się w konieczności wdrażania rozwiązań zapobiegających negatywnym konsekwencjom występującym w rozmaitych obszarach. Rozwój pandemii nie pozostał obojętny dla wymiaru sprawiedliwości i działalności ustawodawczej ${ }^{1}$. Reakcja polskiego ustawodawcy przejawiająca się wprowadzeniem do porządku prawnego licznych aktów prawnych zmierzających do stabilizacji sytuacji prawnej w wielu obszarach dotkniętych COVID-19 w konsekwencji doprowadziła do wykreowania postanowień wywołujących kontrowersje i wątpliwości interpretacyjne. Trudności spowodowane COVID-19 uwypukliły znaczenie zdolności i umiejętności sektora publicznego do radzenia sobie z sytuacjami kryzysowymi, a także szczególnych, wymaganych do rozwiązywania problemów społecznych. Pandemia podkreśliła również znaczenie sektora publicznego jako narzędzia kształtującego rynek, a nie tylko podmiotu zajmującego się jego naprawianiem² ${ }^{2}$ Boryka się on zarówno ze złożonym problemem w zakresie zapewnienia ciągłości funkcjonowania

1 J. Gąsiorowski, Ograniczenia, możliwości i funkcjonowanie sądownictwa powszechnego i stałych sadów polubownych w sprawach cywilnych podczas trwania epidemii w Polsce, ADR. Arbitraż i Mediacja 2020, nr 2, s. 53.

2 M. Mazzucato, From Market Fixing to Market Creating: A New Framework for Innovation Policy, Industry and Innovation 2016, t. 23, s. 140-156. 
organów administracji publicznej, jak i z burzliwymi trudnościami charakteryzującymi się pojawieniem się niespójnych rozwiązań legislacyjnych, co wpływa na dezorientację pracowników instytucji zarządzających regionalnym programem operacyjnym, jak i beneficjentów funduszy europejskich, wobec których wszczęte zostało postępowanie administracyjne w przedmiocie zwrotu przyznanych środków.

W związku z sygnalizowanymi przez organy administracji publicznej w początkowej fazie pandemii problemami natury praktycznej spowodowanymi jej wybuchem, jednocześnie potęgowanymi niezrozumiałymi i skomplikowanymi regulacjami prawnymi, istotne stało się zwrócenie uwagi na sytuację beneficjentów otrzymujących dofinansowanie w związku z realizacją programów w zakresie polityki spójności subsydiowanych w perspektywie finansowej 2014-2020, wobec których wszczęte zostało postępowanie administracyjne $\mathrm{w}$ przedmiocie zwrotu wraz z odsetkami liczonymi jak dla zaległości podatkowych środków przyznanych $\mathrm{w}$ ramach umowy o dofinansowanie. We wstępnych rozważaniach warto wskazać, że postępowanie to jest efektem prowadzonej na podstawie art. 9 ust. 2 pkt 7 ustawy wdrożeniowej ${ }^{3}$ oraz postanowień umowy o dofinasowanie kontroli planowej projektu, z ustaleń której sporządzany jest protokół pokontrolny. $\mathrm{W}$ razie stwierdzenia w toku czynności kontrolnych nieprawidłowości bądź też naruszeń postanowień obowiązujących aktów prawnych, instytucja zarządzająca (dalej: IZ), którą jest zarząd województwa w przypadku zarządzania regionalnym programem operacyjnym (dalej: RPO), wzywa beneficjenta na podstawie art. 207 ust. 8 ustawy o finansach publicznych ${ }^{4}$ do zwrotu środków w określonej wysokości wraz z odsetkami ustalonymi jak dla zaległości podatkowych w określonym terminie. Co istotne, na etapie odzyskiwania środków unijnych i środków uzupełniających z dotacji celowej pochodzącej z budżetu państwa zastosowanie znajduje procedura administracyjna, w tym wydawanie decyzji o zwrocie na podstawie przepisów Kodeksu postępowania administracyjnego ${ }^{5}$. Niepodatkowe należności budżetowe mają charakter publicznoprawny i wynikają one $\mathrm{z}$ relacji zachodzących pomiędzy dwoma podmiotami w zakresie uprawnień lub obowiązków wynikających z określonych norm prawnych, $\mathrm{w}$ których brak jest równorzędności podmiotów. Z tego też względu konkretyzacja tego rodzaju uprawnień lub obowiązków jednostki następuje

3 Ustawa z dnia 11 lipca 2014 r. o zasadach realizacji programów w zakresie polityki spójności finansowanych w perspektywie finansowej 2014-2020, tekst jednolity: Dz. U. z 2020 r. poz. 818 (dalej: ustawa wdrożeniowa).

4 Ustawa z dnia 27 sierpnia 2009 r. o finansach publicznych, tekst jednolity: Dz. U. z2019 r. poz. 869 z późn. zm. (dalej: u.f.p.).

5 Ustawa z dnia 14 czerwca 1960 r. - Kodeks postępowania administracyjnego, tekst jednolity: Dz. U. z 2020 r. poz. 256 (dalej: K.p.a.). 
w drodze decyzji administracyjnej ${ }^{6}$. W związku z brakiem dokonania całościowego zwrotu w wyznaczonym $\mathrm{w}$ wezwaniu terminie wobec beneficjenta wszczynane jest postępowanie administracyjne, któremu towarzyszy poinformowanie go o przysługującym prawie do czynnego udziału $\mathrm{w}$ postępowaniu, $\mathrm{w}$ tym przeglądania akt sprawy, uzyskania wyjaśnień, składania wniosków dowodowych. Z uwagi na wprowadzone liczne ograniczenia nie tylko prawne, ale i obostrzenia oraz rozwiązania zmierzające $\mathrm{z}$ jednej strony do wyizolowania jednostek zakażonych, $\mathrm{z}$ drugiej zaś - zminimalizowania ryzyka rozwoju epidemii w Polsce, możliwość aktywnego uczestniczenia beneficjentów we wszczętych postępowaniach administracyjnych była niejednokrotnie utrudniona.

W konsekwencji nasilającej się pandemii i wzrastającej liczby zakażeń w dniu 20 marca 2020 r. wprowadzony został w Polsce stan epidemii. Inicjatywy zmierzające do stworzenia nowych, nieznanych dotąd reguł funkcjonowania w społeczeństwie systematycznie okazywały się niewystarczające, co doprowadziło do konieczności bieżącego reagowania ustawodawcy na zachodzące przemiany. Prowadzenie wszelkiego rodzaju postępowań, w tym administracyjnych, wobec beneficjentów środków unijnych w okresie epidemii koronawirusa w dalszym ciągu stwarza wiele problemów, z którymi muszą zmierzyć się wszystkie organy administracji publicznej oraz ich pracownicy ${ }^{7}$. Pandemia - jak wskazano - ujawniła obszary, których dokładniejsze uregulowanie ma kluczowe znaczenie dla możliwie jak najbardziej prawidłowego funkcjonowania społeczeństwa w następstwie kryzysu. Jednym z przejawów jest zdolność dostosowania usług publicznych do potrzeb obywateli, czego wyrazem są najważniejsze - z punktu widzenia niniejszego opracowania regulacje $w$ tym zakresie zawarte $w$ ustawach regulujących szczególne rozwiązania związane z zapobieganiem, przeciwdziałaniem i zwalczaniem COVID- $19^{8}$, jak też w ustawie o szczególnych rozwiązaniach wspierających realizację programów operacyjnych w związku z wystąpieniem COVID-19 w 2020 r. ${ }^{9}$, w której skonstruowane zostały postanowienia szczególne odnoszące się wprost do sytuacji beneficjenta środków unijnych. Kwestie te precyzyjnie zostaną przybliżone w dalszej części

6 Wyrok NSA z dnia 12 października 2018 r., I GSK 1015/18, Legalis nr 1849756.

7 A. Klich, Electronic Communication with Public Administration in the Time of COVID-19 - Poland's Experience, International Journal of Environmental Research and Public Health 2021, t. 18, nr 2 (685), s. 2, doi: 10.3390/ijerph18020685, s. 2.

8 Ustawa z dnia 2 marca 2020 r. o szczególnych rozwiązaniach związanych z zapobieganiem, przeciwdziałaniem i zwalczaniem COVID-19, innych chorób zakaźnych oraz wywoływanych nimi sytuacji kryzysowych, Dz. U. z 2020 r. poz. 374 z późn. zm. (dalej: COVID-19U), a także ustawy ją nowelizujące.

9 Ustawa z dnia 3 kwietnia 2020 r. o szczególnych rozwiązaniach wspierających realizację programów operacyjnych w związku z wystąpieniem COVID-19 w 2020 r., Dz. U. z 2020 r. poz. 694 (dalej: specustawa funduszowa). 
opracowania, z uwagi bowiem na ich kaskadowy i niełatwy charakter konieczne jest wyraźne wyodrębnienie czasookresów, w których regulacje te miały bądź mają zastosowanie.

Celem niniejszego opracowania jest próba ustalenia dopuszczalnego zakresu funkcjonowania organów administracji publicznej prowadzących w czasie COVID-19 tzw. postępowania zwrotowe wobec beneficjentów środków unijnych, w szczególności w zakresie możliwości ich zawieszania lub wydłużania przewidzianych przepisami prawa terminów na dokonanie określonych czynności. Biorąc pod uwagę chaotyczność ustawodawcy i incydentalne wprowadzanie regulacji o krótkim czasie obowiązywania (np. wstrzymanie zawieszenia z mocy prawa terminów postępowania administracyjnego trwało na mocy art. 15zzs COVID-19U od 31 marca 2020 do 16 maja 2020 r.), dość istotna jest także kwestia dopuszczalności i skuteczności wydawania przez organ decyzji w przedmiocie zwrotu w okresie stanu zagrożenia epidemicznego lub stanu epidemii ogłoszonego z powodu COVID-19. Niestety z uwagi na ograniczone ramy niniejszego opracowania, a także $z$ uwagi na to, że rozważania te miałyby w głównej mierze walor historyczny, w opracowaniu omówiono te zagadnienia w niezbędnym zakresie, szczegółowo zaś skoncentrowano się na próbie udzielenia odpowiedzi na pytanie o to, jak powinny wyglądać postępowania zwrotowe w czasie pandemii, a także czy mogą być one zawieszane na wniosek beneficjentów. Zagadnienia te są bowiem trzonem problemu badawczego stanowiącego przedmiot analizy niniejszego opracowania, co jest uzasadnione przede wszystkim sytuacją, w jakiej znaleźli się beneficjenci, która z dużym stopniem prawdopodobieństwa mogła ulec znacznemu pogorszeniu w związku z pandemią spowodowaną COVID-19, niezależnie od uprzednio przeprowadzonej kontroli planowej, w wyniku której stwierdzone zostały nieprawidłowości w realizacji projektów.

\section{Dopuszczalny zakres funkcjonowania organu w czasie COVID-19}

Podejmując próbę odpowiedzi na pytania dotyczące zasad prowadzenia postępowań administracyjnych w stanie zagrożenia epidemicznego oraz stanu epidemii, należy ustalić właściwą hierarchię przepisów ustaw określających szczególne rozwiązania związane z zapobieganiem, przeciwdziałaniem i zwalczaniem COVID-19, innych chorób zakaźnych oraz wywołanych nimi sytuacji kryzysowych oraz określających szczególne instrumenty wsparcia w związku z rozprzestrzenianiem się wirusa SARS-CoV-2. Kaskadowy charakter przepisów ustaw K.p.a., COVID-19U 
i ustaw ją nowelizujących oraz sp.fund. wymusza konieczność ustalenia zasad związania organu postanowieniami określającymi sposób funkcjonowania organu w dobie COVID-19. Przyjąć w tym zakresie należy, że specustawa funduszowa z dnia 3 kwietnia 2020 r., której postanowienia obowiązują od 18 kwietnia 2020 r., stanowi lex specialis względem obowiązującej od 31 marca 2020 r. COVID-19U, która z kolei jest lex specialis względem postanowień K.p.a. Z tego też względu na organie administracji publicznej ciążył obowiązek dokonywania ze szczególną uwagą i ostrożnością analizy postanowień wskazanych aktów prawnych w zakresie zawieszenia postępowań administracyjnych oraz skutków z tym związanych. W pierwszym okresie pandemii fundamentalne znaczenie z perspektywy postępowań administracyjnych miało brzmienie obowiązującego do dnia 16 maja 2020 r. art. 15zzs COVID-19U. Nie należy jednak pomijać faktu, że w tym czasie doszło do swoistego „nałożenia” się regulacji normujących zasady prowadzenia postępowań administracyjnych in genere z postępowaniami prowadzonymi wobec beneficjentów środków unijnych, co uzasadnione jest obowiązywaniem od 18 kwietnia 2020 r. specustawy funduszowej. W konsekwencji w okresie 31 marca - 18 kwietnia 2020 r. mieliśmy do czynienia ze zdublowanym stanem prawnym w zakresie przesłanek uzasadniających zawieszenie postępowań administracyjnych prowadzonych wobec beneficjentów środków unijnych.

Do momentu obowiązywania art. 15zzs COVID-19U nie było właściwe interpretowane jego brzmienie w sposób eliminujący jednoczesne uwzględnienie postanowień art. 19 sp.fund. Pierwsza ze wskazanych regulacji statuowała ogólną zasadę dotyczącą m.in. zawieszania biegu terminów sądowych i procesowych w związku z określeniem przez ustawodawcę ogólnych możliwych rozwiązań związanych z zapobieganiem, przeciwdziałaniem i zwalczaniem COVID-19, innych chorób zakaźnych oraz wywołanych nimi sytuacji kryzysowych. Z kolei postanowienia specustawy funduszowej statuują szczególne i nadzwyczajne rozwiązania umożliwiające podejmowanie działań niwelujących negatywny wpływ pandemii na wdrażanie i realizację programów operacyjnych. $Z$ tego też względu w przypadku regulowania przez wskazane ustawy tych samych zagadnień, pierwszeństwo w tym zakresie mają postanowienia specustawy funduszowej, w pozostałym zakresie zaś należy stosować przepisy COVID-19U oraz K.p.a.

W związku z w wejściem w życie z dniem 31 marca 2020 r. art. 15zzs COVID-19U w praktyce dostrzegalne były liczne wątpliwości interpretacyjne, co odnoszono do prowadzonych przez organy administracji publicznej postępowań administracyjnych. Zgodnie z brzmieniem przywołanego art. 15zzs ust. 1 pkt 6 COVID-19U $\mathrm{w}$ okresie stanu zagrożenia epidemicznego lub stanu epidemii ogłoszonego z powodu COVID bieg terminów procesowych i sądowych w postępowaniach 
administracyjnych nie rozpoczynał się, a rozpoczęty ulegał zawieszeniu na ten okres. Regulacja ta, której zakres nie ograniczał się wyłącznie do postępowań administracyjnych od samego początku jej obowiązywania, wywoływała kontrowersje wyrażane zarówno przez przedstawicieli praktyki, jak i nauki. Przyczyną takiego stanu rzeczy było przede wszystkim to, że analizowane postanowienie ustawy wywierało wpływ jedynie na bieg terminów procesowych, natomiast nie wpływało na bieg terminów prawa materialnego w odniesieniu do terminów prawa cywilnego ${ }^{10}$. Nie dotyczyło to jednak terminów prawa administracyjnego, których bieg zgodnie z dodanym ustawą z dnia 31 marca 2020 r. nowelizującą ustawę COVID-19 art. $15 z z z r^{11}$ nie rozpoczynał się, a rozpoczęty ulegał zawieszeniu na ten okres. Spotęgowanie negatywnej fali reakcji na brzmienie art. 15zzs COVID-19U nastąpiło w maju 2020 r., gdy przepis ten został uchylony, ustawodawca zaś zdecydował się na wznowienie i rozpoczęcie biegu wszystkich terminów, których bieg nie rozpoczął się bądź został zawieszony na mocy pierwotnych przepisów COVID-19U, po upływie 7 dni od wejścia w życie nowelizacji z dnia 14 maja 2020 r. ${ }^{12}$ Wątpliwy pozostał sposób uchylenia omawianej regulacji, który wzbudził kontrowersje dotyczące przede wszystkim końca okresu jej obowiązywania ${ }^{13}$. Mimo uchylenia art. 15zzs COVID-19U i obowiązywania postanowień sp.fund. analizowana problematyka pozostawała aktualna $\mathrm{z}$ uwagi na ocenę skuteczności wydanych w okresie 1-18 kwietnia 2020 r. decyzji orzekających zwrot środków od beneficjentów, jak i innych czynności dokonanych przez organ administracji publicznej. Z uwagi na ograniczone ramy niniejszego opracowania warto w tym zakresie jedynie wskazać, że z uwagi na specyfikę analizowanego zagadnienia dopuszczalności wydawania przez organ decyzji należy upatrywać przez pryzmat postanowień sp.fund. oraz postanowień COVID-19U i ustaw ją nowelizujących. Wydaje się, iż ratio legis przepisów odnoszących się do sposobu podejmowania czynności przez organ w toku postępowania administracyjnego zmierza do uznania, iż organ powinien $\mathrm{w}$ miarę możliwości prowadzić postępowania administracyjne na dotychczasowych zasadach, stosując jednocześnie ułatwienia względem stron, które statuuje ustawodawca.

10 R. Kulski, Wpływ stanu zagrożenia epidemicznego lub stanu epidemii ogłoszonego z powodu COVID-19 na postępowanie cywilne, Monitor Prawniczy 2020, nr 9, s. 445.

11 Ustawa z dnia 31 marca 2020 r. o zmienia ustawy o szczególnych rozwiązaniach związanych z zapobieganiem, przeciwdziałaniem i zwalczaniem COVID-19, innych chorób zakaźnych oraz wywoływanych nimi sytuacji kryzysowych oraz niektórych innych ustaw, Dz. U. z 2020 r. poz. 568.

12 J. Gąsiorowski, Ograniczenia, możliwości i funkcjonowanie..., s. 59; ustawa nowelizująca COVID-19U z dnia 14 maja 2020 r., Dz. U. z 2020 r. poz. 875.

13 W. Piłat, Komentarz do art. 15zzs COVID-19U, w: Ustawa o szczególnych rozwiązaniach związanych z zapobieganiem, przeciwdziałaniem i zwalczaniem COVID-19, innych chorób zakaźnych oraz wywołanych nimi sytuacji kryzysowych. Komentarz, red. K. Szmid, 2020 [baza danych Legalis], Nb. 21. 
Interpretację taką potwierdza obowiązujący od 18 kwietnia 2020 r. art. 15zzzzzn COVID-19U ${ }^{14}$, którego brzmienie umożliwia stwierdzenie, iż postępowania miały i w dalszym ciągu mają toczyć się przy wdrożeniu nadzwyczajnych instrumentów w celu ułatwienia go zarówno stronom, jak i organowi. Należy zwrócić także uwagę na deklaratoryjny charakter decyzji określającej przypadającą do zwrotu kwotę dofinansowania. Potwierdza to stanowisko judykatury, zgodnie z którym decyzja wydana na podstawie przepisu art. 207 u.f.p. ma taki charakter, nie tworzy ona bowiem nowego stosunku prawnego. Obowiązek zwrotu powstaje z chwilą zaistnienia przesłanek przewidzianych przepisami prawa, ma jedynie pomocniczy charakter. Z tego też względu należy uznać, że decyzja orzekająca o zwrocie środków przez beneficjenta nie jest decyzją konstytutywną ${ }^{15}$. Zasadne wydaje się także objęcie dopuszczalnym zakresem działania organu nie tylko czynności, takich jak wydawanie postanowień o przedłużeniu postępowania, informowanie o zamiarze zakończenia postępowania, wydawania postanowień w zakresie przyjęcia/odrzucenia wniosków dowodowych, ale również możliwość podejmowania tzw. decyzji zwrotowych, które - jak wskazano - nie kształtują nowego stanu prawnego, ale stwierdzają dotychczas istniejące okoliczności uzasadniające orzeczenie np. zwrotu środków. Aktualnie istotne jest pouczenie stron postępowania o brzmieniu art. 19 sp.fund. w zakresie wydłużenia terminu do prowadzenia postępowań administracyjnych w przedmiocie należności, o których mowa w art. 60 pkt 6 u.f.p. oraz o możliwości zawieszenia postępowania na mocy art. 20 sp.fund. w sytuacji, gdy na skutek wystąpienia COVID-19 prowadzenie postępowania administracyjnego w odniesieniu do środków unijnych jest niemożliwe lub utrudnione.

Kumulatywna analiza postanowień COVID-19U i ustaw ją nowelizujących, a także sp.fund. prowadzi do wniosku, iż zamierzeniem ustawodawcy nie było zachęcanie organu prowadzącego postępowanie do bierności z uwagi na potencjalną możliwość zawieszenia terminów procesowych przewidzianą do 16 maja $2020 \mathrm{r}$. (a de facto do 23 maja 2020 r. z uwagi na brzmienie przepisów przejściowych). Przesądzało o tym choćby brzmienie art. 15zzs ust. 7 COVID-19U, zgodnie z którym czynności dokonane w okresie stanu zagrożenia epidemicznego lub epidemii w postępowaniach i kontrolach, w tym w postępowaniu administracyjnym, były skuteczne (np. wydane po 31 marca 2020 r. decyzje administracyjne). Potwierdzeniem dla takiej argumentacji jest również - jak wskazano - wprowadzenie art. 15zzzzzn statuującego możliwość uczestniczenia strony w postępowaniu administracyjnym przez Internet. Ustawodawca przewidział możliwość odstąpienia od fundamentalnych

14 Dodany ustawą z dnia 16 kwietnia 2020 r. o szczególnych instrumentach wsparcia w związku z rozprzestrzenianiem się wirusa SARS-COV-2, Dz. U. z 2020 r. poz. 695.

15 Wyrok NSA z dnia 11 października 2018 r., I GSK 931/18, Legalis nr 1849910. 
zasad postępowania administracyjnego. Wprowadzone zmiany w tym zakresie zasadniczo dotyczą trzech obszarów. Ratio legis tego rozwiązania zmierza z jednej strony do zwiększenia uprawnień organu administracji publicznej, z drugiej zaś ma na celu umożliwienie w miarę bieżące funkcjonowania organu, co ocenić należy pozytywnie z perspektywy potencjalnej możliwości zablokowania jego funkcjonowania.

Ustawodawca dopuścił także możliwość odstąpienia od zasady wysłuchania stron, uregulowanej w art. $10 \$ 1$ K.p.a., zgodnie z którym organy administracji publicznej obowiązane są zapewnić stronom czynny udział w każdym stadium postępowania, a przed wydaniem decyzji umożliwić im wypowiedzenie się co do zebranych dowodów i materiałów oraz zgłoszonych żądań. Przesłanką do skorzystania $\mathrm{z}$ tego uprawnienia jest istnienie stanu zagrożenia epidemicznego lub stanu epidemii, w szczególności gdy organ administracji publicznej wykonuje zadania w sposób wyłączający bezpośrednią obsługę interesantów. W takim przypadku organ może odstąpić od zapewnienia stronom czynnego udziału w każdym stadium postępowania, a przed wydaniem decyzji może on odstąpić od umożliwienia im wypowiedzenia się co do zebranych dowodów i materiałów oraz zgłoszonych żądań. Uprawnienie organu może być realizowane także wtedy, gdy wszystkie strony zrzekły się swego prawa.

Ponadto organ - w trakcie istnienia stanu zagrożenia epidemicznego lub stanu epidemii - może zapewnić stronie udostępnienie akt sprawy lub poszczególnych dokumentów stanowiących akta sprawy również za pomocą środków komunikacji elektronicznej w rozumieniu przepisów ustawy o świadczeniu usług drogą elektroniczną. Udostępnienie tych dokumentów może nastąpić na adres wskazany w rejestrze danych kontaktowych lub inny adres elektroniczny wskazany przez stronę. Rozwiązanie to sprzyja tym sytuacjom, w których nie jest możliwy kontakt osobisty w siedzibie organu w związku z toczącym się postępowaniem. Biorąc pod uwagę odwołanie do przepisów ustawy o świadczeniu usług drogą elektroniczną, niezbędne jest podkreślenie, że przez środki komunikacji elektronicznej rozumie się rozwiązania techniczne, w tym urządzenia teleinformatyczne i współpracujące $\mathrm{z}$ nimi narzędzia programowe, umożliwiające indywidualne porozumiewanie się na odległość przy wykorzystaniu transmisji danych między systemami teleinformatycznymi, a w szczególności pocztę elektroniczną. Z tego też względu udostępnienie przez stronę adresu poczty elektronicznej w rejestrze umożliwia praktyczne zapewnienie stronom dostępu do akt sprawy lub poszczególnych dokumentów stanowiących akta sprawy. W wyniku kompleksowej analizy przepisów regulujących zasady postępowania administracyjnego zasadne wydaje się stwierdzenie, że zamierzeniem ustawodawcy było stworzenie rozwiązań, dzięki którym organ będzie miał możliwość swoistego „odformalizowania” czynności podejmowanych w toku 
stanu zagrożenia epidemicznego lub stanu epidemii poprzez umożliwienie stronie zdalnego dostępu do akt sprawy lub poszczególnych dokumentów stanowiących akta sprawy.

Organ został także uprawniony do przeprowadzenia czynności w toku postępowania wymagającego zgodnie z przepisami prawa osobistego stawiennictwa, również przez udostępnienie przez stronę lub innego uczestnika postępowania swojego wizerunku w czasie rzeczywistym za pośrednictwem transmisji audiowizualnej. Warunkiem do zrealizowania tej możliwości jest sytuacja, w której za takim rozwiązaniem przemawia interes strony, a organ prowadzący postępowanie wyraził na to zgodę. W analizowanym przypadku mowa o tzw. czynnościach odmiejscowionych umożliwiających jednoczesny kontakt organu i strony z wykorzystaniem nowoczesnych rozwiązań technologicznych. Mankamentem tego rozwiązania może być kwestia prawidłowej identyfikacji strony postępowania.

Ratio legis rozwiązań zawartych zarówno w art. 19 specustawy funduszowej, jak i nieobowiązującym już art. 15zzs ust. 7 oraz art. 15zzzzzn COVID-19U przesądza o dążeniu ustawodawcy do zapewnienia w miarę możliwości normalnego funkcjonowania organów administracji publicznej, przy jednoczesnym wprowadzeniu licznych ułatwień dla stron postępowania. $\mathrm{W}$ razie restrykcyjnego przyjęcia, że $\mathrm{w}$ związku $\mathrm{z}$ zawieszeniem postępowań administracyjnych organ pozbawiony jest możliwości funkcjonowania potencjalnie mogłoby dojść do sytuacji, w której mimo możliwości podejmowania działań przez pracowników organu dochodziłoby do kompletnego paraliżu jego funkcjonowania, pomimo braku wyraźnych przesłanek do jednoznacznego braku możliwości podejmowania czynności.

\section{Zasady przedłużania i wstrzymywania terminów w postępowaniach administracyjnych prowadzonych wobec beneficjentów środków unijnych oraz ich zawieszania}

Analizując problematykę zawieszenia postępowania wszczętego wobec beneficjenta środków unijnych, warto podkreślić, że z jego perspektywy art. 15zzs COVID-19U nie był jedyną regulacją odnoszącą się do problematyki zawieszania postępowań administracyjnych, jak bowiem wskazano, istotne są także postanowienia obowiązującej od dnia 18 kwietnia 2020 r. sp.fund. W konsekwencji do czasu uchylenia brzmienia art. 15zzs COVID-19U (tj. do dnia 14 maja 2020 r.) de facto istniały dwie podstawy prawne stwarzające możliwość zawieszenia postępowań administracyjnych. Nie należy jednak traktować tego zabiegu legislacyjnego jako swoistej do- 
wolności w zakresie sformułowania wyraźnej podstawy do wstrzymania lub zawieszenia terminów w postępowaniach administracyjnych prowadzonych w sprawie zwrotu dofinansowania. Poddając gruntownej analizie niniejszego zagadnienia, nie ograniczając się jedynie do interpretacji przepisów prawnych, ale i do praktyki i sytuacji, w jakiej znalazły się IZ RPO, dostrzeżono liczne wątpliwości pracowników organów w zakresie nie tylko tego, czy z praktycznego punktu widzenia decyzje wydane po dniu 1 kwietnia 2020 r., a przed 18 kwietnia 2020 r. były prawnie skuteczne (co zostało omówione w poprzedniej części opracowania), ale przede wszystkim, jakie powinny być zasady prowadzenia postępowań administracyjnych w okresie stanu zagrożenia epidemicznego i stanu epidemii tak w poprzednim, jak i aktualnym stanie prawnym.

Przyczyną takiego stanu rzeczy jest to, że specustawa funduszowa wprowadza regulacje, których celem jest płynna realizacja i rozliczenie projektów dofinansowanych w ramach programów operacyjnych w warunkach kryzysu wywołanego pandemią SARS-CoV-2. Rozwiązania zaproponowane przez ustawodawcę stwarzają instytucjom uczestniczącym w systemie wdrażania środków europejskich podstawę prawną do elastycznego podejścia we wdrażaniu i realizacji projektów objętych dofinansowaniem w ramach programów operacyjnych w związku z wystąpieniem COVID-19. Postanowienia sp.fund. stanowią odpowiedź na konieczność uwzględnienia szczególnych okoliczności spowodowanych COVID-19, w jakich znaleźli się zarówno wnioskodawcy programów unijnych, jak i beneficjenci realizujący umowy o dofinansowanie projektów. Specustawą funduszową wprowadzono szereg regulacji stanowiących wyjątkowe rozwiązania od dotychczas obowiązujących zasad wdrażania i realizacji projektów w ramach programów operacyjnych, przy równoległym obowiązywaniu (do maja 2020 r.) postanowień COVID-19U, w której przewidziano ogólne reguły dotyczące zawieszenia biegu terminów postępowań sądowych i administracyjnych. Z uwagi na to, że - jak wskazano - postanowienia sp.fund. stanowią lex specialis względem postanowień COVID-19U, mają one pierwszeństwo w zakresie ustalenia zasad zawieszenia postępowań administracyjnych prowadzonych względem beneficjentów środków unijnych.

Analizując omawianą problematykę, zasadne wydaje się odniesienie tak do możliwości przedłużania i wstrzymywania terminów w postępowaniach administracyjnych, jak i zawieszania prowadzonych przez organ postępowań. W tym zakresie należy w pierwszej kolejności zwrócić uwagę na brzmienie art. 19 sp.fund., zgodnie z którym w przypadku, gdy na skutek wystąpienia COVID-19 prowadzenie postępowania administracyjnego w odniesieniu do należności, o których mowa w art. 60 pkt 6 u.f.p., jest niemożliwe lub utrudnione, w pierwszej kolejności należy dostrzec przedłużenie terminów na załatwienie sprawy określonych 
$\mathrm{w}$ art. $35 \S 3$ K.p.a., zgodnie bowiem $\mathrm{z}$ art. 19 pkt 1 sp.fund. terminy te ulegają przedłużeniu o 3 miesiące. $W$ analizowanych postępowaniach nie stosuje się także przepisów art. 36-38 K.p.a., które odnoszą się do obowiązku zawiadomienia przez organ o niezałatwieniu sprawy $\mathrm{w}$ terminie, prawie strony do wniesienia ponaglenia oraz odpowiedzialności porządkowej lub dyscyplinarnej pracownika organu, który z nieuzasadnionych przyczyn nie załatwił sprawy $\mathrm{w}$ terminie lub prowadził postępowanie dłużej niż było to niezbędne do załatwienia sprawy. Regulacja ta dotyczy przedłużenia terminów na załatwienie sprawy w związku z postępowaniami prowadzonymi w stosunku do należności z tytułu zwrotu środków przeznaczonych na realizację programów finansowanych z udziałem środków europejskich oraz innych należności związanych z realizacją projektów finansowanych z udziałem tych środków, a także odsetek od tych środków i od tych należności.

Tym samym ustawodawca wprowadził konstrukcję tzw. automatycznego wydłużenia tych postępowań, o ile prowadzenie postępowania administracyjnego w stosunku do wskazanych należności jest niemożliwe lub utrudnione. Wydaje się, że sama sytuacja spowodowana COVID-19 uzasadnia przyjęcie, że mamy do czynienia ze stanem, w którym prowadzenie postępowań jest utrudnione, o niemożliwości prowadzenia postępowań bowiem świadczyłoby np. objęcie kwarantanną wszystkich pracowników organu. Z tego też względu ta przesłanka wydaje się być znacznie utrudniona, a nawet niemożliwa do wykazania. Zestawiając brzmienie art. 19 sp.fund. z art. 15zzs COVID-19U, można było odnieść wrażenie, iż w okresie od 18 kwietnia do 16 maja 2020 r. zakresy obu regulacji wzajemnie się wykluczały. Nie ulega jednak wątpliwości, że w tym przypadku pierwszeństwo z perspektywy postępowań administracyjnych prowadzonych w stosunku do środków unijnych miały i w dalszym ciągu mają postanowienia sp.fund. w zakresie terminu na dokonanie czynności, jak i statuowania możliwości ich dokonania. Mając na uwadze art. 19 sp.fund., należy dostrzec jego wyraźne pierwszeństwo w szczególności przed brzmieniem obowiązującego do dnia 16 maja 2020 r. art. 15zzs ust. 9 COVID-19U w zakresie określenia dopuszczalności podejmowania czynności w toku postępowania administracyjnego, co z perspektywy sp.fund. utożsamiać należy z przedłużeniem tych postępowań o trzy miesiące i legitymacją organu postępowania do podejmowania czynności. Należy wyraźnie podkreślić, że celem, dla którego wprowadzone zostały obie regulacje, jest ułatwienie stronom postępowania administracyjnego funkcjonowania w sytuacji stanu zagrożenia epidemicznego oraz stanu epidemii. Co istotne, przedmiotowe postępowania w sprawie zwrotu mogą zostać zawieszone na uzasadniony wniosek strony albo z urzędu na okres nie dłuższy niż 180 dni. Zgodnie z postanowieniami art. 20 ust 2 sp.fund. za okres zawieszenia nie nalicza się odsetek od dochodzonych od beneficjenta 
należności. Jednocześnie zgodnie z art. 21 sp.fund. ustawodawca upoważnił organ do działania na wniosek stronu lub z urzędu w zakresie wstrzymania wykonania decyzji o zwrocie środków na okres nie dłuższy niż 180 dni. Dodatkowo w celu ograniczenia negatywnych skutków pandemii COVID-19 organy uprawnione są do stosowania - na wniosek zobowiązanego - ulgi w spłacie należności, co wiąże się z legitymacją do umorzenia ich w całości lub w części, jak również do odraczania terminów spłat całości albo części należności lub do rozkładania na raty płatności całości albo części należności.

\section{Postępowania administracyjne w świetle postanowień specustawy funduszowej w dobie COVID-19 - uwagi praktyczne}

W związku z wprowadzeniem przez ustawodawcę rozwiązań legislacyjnych umożliwiających zawieszanie postępowań administracyjnych, ze szczególnym uwzględnieniem regulacji prawnych dotyczących postępowań prowadzonych w przedmiocie zwrotu przyznanych środków, IZ RPO województw informując beneficjentów o wszczęciu postępowań, powiadamiały jednocześnie o możliwości skorzystania $\mathrm{z}$ uprawnień przewidzianych przez ustawodawcę $\mathrm{w}$ związku z sytuacją wystąpienia COVID-19. Jak wskazano, celem sp.fund. jest zapewnienie płynnej realizacji i rozliczania projektów, jej postanowienia zaś miały w sposób pozytywny oddziaływać na sytuację beneficjentów. Założenie to wyrażało się przede wszystkim w umożliwieniu nie tylko instytucjom uczestniczącym we wdrażaniu środków europejskich, ale i podmiotom ubiegającym się o wsparcie, jak i beneficjentom, którzy wsparcie finansowe uzyskali przed ogłoszeniem stanu zagrożenia epidemicznego lub stanu epidemii. Rozwiązania zaproponowane przez ustawodawcę cechują się większą elastycznością zarówno w działaniu organów administracji publicznej względem podmiotów aplikujących o środki unijne, jak i ich beneficjentom. Podejście to zasługuje na aprobatę, szczególna sytuacja bowiem, w której znaleźli się nie tylko aplikujący, ale i beneficjenci środków unijnych, może w sposób negatywny wpływać na sposób realizacji postanowień umowy o dofinansowanie, a w przypadku prowadzonych postępowań administracyjnych w przedmiocie zwrotu tych środków - może bezpośrednio wpływać na pogorszenie ich aktualnej sytuacji nierzadko spowodowanej COVID-19.

Beneficjenci powołując się na regulacje prawne ujęte w art. 19-20 sp.fund., wnosili o zawieszenie postępowania administracyjnego w odniesieniu do należności, o których mowa w art. 60 pkt 6 u.f.p. na okres 180 dni. Analizując dane 
pochodzące z 50\% województw ${ }^{16}$, możliwe jest pozorne stwierdzenie, że skala tego zjawiska wbrew pozorom nie była i nie jest aż tak duża. Jednostkowa analiza danych statystycznych pochodzących z 8 instytucji zarządzania regionalnym programem operacyjnym lub innymi programami unijnymi prowadzić może do pozornego stwierdzenia małej liczby sytuacji, w której aktualizowała się konieczność analizy postanowień tak COVID-19U, jak i sp.fund. Rzeczywiście, biorąc pod uwagę np. dane pochodzące z województwa kujawsko-pomorskiego, pomorskiego, lubuskiego czy mazowieckiego ${ }^{17}$, w których nie odnotowano ${ }^{18}$ sytuacji dotyczących zawieszenia prowadzenia tego rodzaju postępowań, możliwe jest podawanie w wątpliwość zasadności wprowadzenia przez ustawodawcę analizowanych regulacji umożliwiających tak wstrzymanie wykonania decyzji zwrotowej, jak i zawieszenia postępowania administracyjnego. Podobny wniosek może być formułowany względem tych IZ RPO, w których liczba zarówno wniosków beneficjentów, jak i przypadków działania z urzędu przez organ ogranicza się do zaledwie kilku przypadków. Pozornie wydawać się może, że jedno zawieszone postępowanie spośród wszystkich prowadzonych przez tę IZ RPO to stosunkowo niska liczba. Przykładowo w IZ RPO województwa lubelskiego ogólna liczba postępowań prowadzonych w okresie, w którym wystąpiły przypadki zawieszenia i wstrzymania postępowań, tj. do końca października 2020 r., wynosiła 56, spośród których 5,35\% postępowań zostało zawieszonych (1 postanowienie na podstawie art. 20 sp.fund., 2 postanowienia na podstawie art. 21 ust. 1 i 2 sp.fund..$^{19}$ ). Zdecydowanie większy odsetek procentowy postępowań zawieszonych obserwowany jest w województwach małopolskim i zachodniopomorskim. W przypadku postępowań w przedmiocie zwrotu dofinansowania prowadzonych przez IZ RPO Województwa Małopolskiego dotychczas na podstawie art. $20 \mathrm{i}$ art. 21 sp.fund. zawieszone zostały 3 postępowania spośród 14 prowadzonych w przedmiocie odzyskiwania należności, co stanowi 14,3\% liczby wszystkich prowadzonych postępowań, na etapie poprzedzającym zaś wszczęcie postępowania egzekucyjnego (tj. po zakończeniu postępowań administracyjnych) na 11 spraw wstrzymano wykonanie 1 decyzji, co stanowi 9\%. Z kolei

16 Przedstawione w niniejszej publikacji dane pochodzą od właściwych jednostek organizacyjnych urzędów marszałkowskich w województwach: kujawsko-pomorskim, lubelskim, lubuskim, małopolskim, mazowieckim, pomorskim oraz zachodniopomorskim. Autorka dokonała opracowania własnego danych otrzymanych z powyższych instytucji zarządzających RPO.

17 W przypadku województwa mazowieckiego brak zawieszonych postępowań dotyczy wyłącznie zawieszenia postępowań w oparciu o art. 20 sp.fund.

18 Dane z województwa pomorskiego aktualne na dzień 17 listopada 2020 r., z województwa kujawsko-pomorskiego - na dzień 29 października 2020 r., z województwa lubuskiego - na dzień 23 listopada 2020 r., z województwa mazowieckiego - na dzień 10 listopada 2002 r.

Dane aktualne na dzień 9 listopada $2020 \mathrm{r}$. 
w przypadku IZ RPO Województwa Zachodniopomorskiego zawieszono 5 spośród 20 prowadzonych postępowań administracyjnych, co stanowi $25 \%{ }^{20}$. Analizując sytuację w pozostałych pięciu instytucji zarządzających, które udostępniły dane dotyczące liczby zawieszonych postępowań, należy wskazać, że nie jest możliwe ustalenie ogólnej tendencji i stosunku procentowego zawieszonych postępowań (zarówno na podstawie art. 20, jak i art. 21 ust. 1 i 2 sp.fund.) w sposób kreujący ogólny obraz w skali całego kraju.

Zestawiając ją jednak z ogólną liczbą wszczętych i prowadzonych postępowań administracyjnych, procentowo wydaje się, że beneficjenci - po uprzednim pouczeniu ich o możliwość zawieszenia postępowania - postępowali zgodnie z założeniem ustawodawcy stwarzającym możliwość do swoistego oddalenia w czasie negatywnych skutków niezrealizowania projektu, w szczególności zgodnie z postanowieniami umowy o dofinansowanie i odpowiednimi regulacjami mającymi zastosowanie $\mathrm{w}$ danym przypadku. $\mathrm{Z}$ tego też względu nie należy krytycznie podchodzić do przekazanych na potrzeby niniejszego opracowania informacji statystycznych. Analizowanie jednostkowej liczby zawieszonych na wniosek beneficjenta lub z urzędu z uwagi na negatywne konsekwencje, jakie spowodował COVID-19, postępowań administracyjnych prowadzić może do mylnej oceny braku zasadności wprowadzonych przez ustawodawcę rozwiązań usprawniających procedurę odzyskiwania przez IZ RPO środków.

\section{Zakończenie}

Zamierzeniem niniejszej publikacji było przedstawienie zagadnień normujących dopuszczalny zakres funkcjonowania organów administracji publicznej prowadzących w czasie COVID-19 tzw. postępowania zwrotowe wobec beneficjentów środków unijnych, w szczególności w zakresie możliwości ich zawieszania lub wydłużania przewidzianych przepisami prawa terminów na dokonanie określonych czynności. Jak wskazano, ustawodawca wprowadził szereg uregulowań umożliwiających postawienie tezy, zgodnie z którą jego zamierzeniem nie było zachęcanie organu prowadzącego postępowanie do bierności z uwagi na potencjalną możliwość zawieszenia terminów procesowych czy też wydłużania postępowań. Ustawodawca przewiduje możliwość elastycznego stosowania od fundamentalnych zasad postępowania administracyjnego, co wyraża się w uprawnieniu organu do odstąpienia od zasady 
wysłuchania stron, uregulowanej w art. $10 \$ 1$ K.p.a., stanowiącej jeden $\mathrm{z}$ istotnych elementów koncepcji natural justice, która zdaniem M. Jaśkowskiej obejmuje zasady naturalnej sprawiedliwości i zakłada, że istnieje minimum wymagań pozwalających uznać daną procedurę za poprawną lub rzetelną ${ }^{21}$. Obowiązująca od dnia 18 kwietnia 2020 r. specustawa funduszowa wprowadziła liczne rozwiązania korzystne z punktu widzenia beneficjentów. Poza omówionymi zasadami zawieszania postępowań administracyjnych w przedmiocie zwrotu środków unijnych, uregulowaniem bardzo korzystnym z perspektywy beneficjentów zobowiązanych do zwrotu dofinansowania jest wyłączenie stosowania art. 207 ust. 4 pkt 3 u.f.p., w sytuacji gdy niedokonanie zwrotu środków $\mathrm{w}$ terminie związane było $\mathrm{z}$ pandemią. W związku z powyższym nie stosuje się wobec beneficjenta sankcji polegającej na wykluczeniu go z możliwości otrzymania dofinansowania unijnego w przyszłości, aż do upływu okresu trzech lat od dnia, w którym środki zostaną ostatecznie zwrócone, z czym wiąże się jednocześnie wpis do rejestru podmiotów wykluczonych z możliwości otrzymania środków europejskich, prowadzonego przez Ministra Finansów.

Zamierzeniem autorki było także zwrócenie uwagi na praktyczny aspekt stosowania regulacji wprowadzanych $\mathrm{w}$ związku $\mathrm{z}$ ogłoszonym stanem zagrożenia epidemicznego i epidemii. Sformułowane wnioski oparte są na doświadczeniu wynikającym ze współpracy i świadczenia wsparcia prawnego w analizowanym zakresie, przy jednoczesnym wykorzystaniu danych pochodzących z ośmiu IZ RPO, jak i na zastosowanych metodach badawczych (od porównawczej, przez analitycznej, po empiryczną opartą na obserwacji i analizie praktycznych problemów wynikających ze współpracy autora z polską instytucją zarządzającą). Należy jednak zauważyć, że mimo akcentowanych niejednokrotnie przez opinię publiczną wadliwości zaproponowanych przez ustawodawcę rozwiązań, z perspektywy beneficjentów środków unijnych powstające wątpliwości nie miały charakteru dominującego. $Z$ informacji pochodzących od IZ RPO wynika bowiem, że do czasu wprowadzenia postanowień specustawy funduszowej w praktyce nie dochodziło do zawieszania postępowań z przesłanek wynikających z K.p.a. Dostrzegalne były incydentalne wnioski o zawieszenie kierowane przez beneficjentów (np. powoływanie się na instytucję zagadnienia wstępnego). Wprowadzenie do polskiego systemu prawnego specustawy funduszowej spowodowało, że beneficjenci powołując się na wpływ COVID-19 na ich sytuację gospodarczą, zaczęli kierować wnioski, które zasadniczo były rozpatrywane pozytywnie (np. w przypadku wniosków kierowanych do IZ RPO województwa zachodniopomorskiego wszystkie były rozpatrzone). Zarówno w początkowym

21 M. Jaśkowska, w: Instytucje prawa administracyjnego, red. R. Hauser, Z. Niewiadomski, A. Wróbel, Warszawa 2015, s. 295. 
okresie pandemii, jak i aktualnie dostrzegalne jest również korzystanie przez beneficjentów z możliwości wstrzymania wykonania decyzji administracyjnej na podstawie art. 21 sp.fund. I choć nie jest to duża liczba wniosków (np. w województwie mazowieckim na tej podstawie postępowanie było wstrzymane zostało jeden raz), to licząc tę liczbę w stosunku do decyzji zobowiązujących do zwrotu środków (bez decyzji umarzających postępowanie i uchylonych do ponownego rozpatrzenia przez organ I instancji) wydanych w II instancji postępowania administracyjnego w 2020 r. nie jest to liczba mała (w województwie mazowieckim jest to 4,76\%).

Konkludując, argumenty podnoszone przez beneficjentów i przywoływanie przez nich zdarzeń świadczących o wystąpieniu okoliczności utrudniających prowadzenie postępowań administracyjnych zasadniczo wykazywało wystąpienie przesłanki ujętej w art. 19 sp.fund., co skutkowało zawieszeniem postępowań na maksymalny możliwy czas, tj. 180 dni. Jednocześnie beneficjenci uzasadniając składane przez siebie wnioski, wskazywali na skomplikowany charakter postępowań administracyjnych, który wymaga czynnego udziału strony w czynnościach procesowych, co z kolei jest wysoce utrudnione $z$ uwagi na ogłoszony stan zagrożenia epidemicznego i epidemii. Istotne jest jednak to, że dokonując oceny przesłanek uzasadniających zawieszenie postępowania, w pierwszej kolejności stwierdzone powinny zostać okoliczności prowadzące do niemożliwości lub utrudnienia, o których mowa w art. 19 pkt 1 sp.fund., pozostające w związku przyczynowym z COVID-19 (conditio sine qua non). Niezbędne jest również ustalenie, czy nie istniały inne przyczyny niż COVID-19, których wpływ na zaistniałą sytuację był dominujący, i czy organ dochował należytej staranności w ewentualnym przeciwdziałaniu tym przyczynom. Omawiana regulacja nie może być pretekstem do usprawiedliwiania zwykłej, nieterminowej praktyki wydawania rozstrzygnięć przez dany organ ${ }^{22}$. Przyczynami, dla których beneficjenci mogą wnioskować o zawieszenie wszczętych postępowań administracyjnych, mogą być m.in. trudności natury organizacyjno-technicznej polegające na konieczności ograniczenia bezpośredniego kontaktu, co może wpływać w sposób negatywny na możliwość podjęcia skutecznych działań w zakresie m.in. składania wyjaśnień, zgłoszenia wniosków dowodowych i zarzutów w sprawie, jak też weryfikacji dokumentów, pism i opinii, będących przedmiotem stawianych przez organ zarzutów i stwierdzonych nieprawidłowości w realizacji projektu, skutkujących wszczęciem postępowania administracyjnego. Argumentem przemawiającym za zawieszeniem postępowania administracyjnego jest to, że w stanie epidemii siły i środki beneficjentów skoncentrowane są

22 J. Ostałowski, w: Szczególne rozwiązania wspierające realizacje programów operacyjnych $w$ związku $z$ wystapieniem COVID-19 w 2020 r. Komentarz, Gdańsk 2020, art. 19, https://sip.lex.pl/\#/comment ary $/ 587830858 / 628298$ ?keyword=specustawa $\% 20$ wdro\%C5\%BCeniowa\&tocHit=1\&cm=STOP [dostęp: 2.12.2020 r.]. 
na utrzymaniu dotychczasowego poziomu przychodów celem zachowania płynności finansowej i minimalizacji ryzyka redukcji etatów.

Dokonując kumulatywnej oceny regulacji odnoszących się do postępowań administracyjnych w przedmiocie zwrotu środków unijnych wynikających zarówno z COVID-19U, jak i sp.fund., zasadne wydaje się dostrzeżenie dążenia ustawodawcy do stworzenia organowi warunków do prowadzenia postępowań administracyjnych, przy jednoczesnym wdrożeniu szeregu ułatwień dla stron postępowania. Ratio legis tych unormowań przesądza o możliwości zwiększenia z jednej strony uprawnień organu, z drugiej zaś ma na celu umożliwienie w miarę bieżące jego funkcjonowanie, co ocenić należy pozytywnie z perspektywy dążenia do uniknięcia sytuacji, w której - w razie obowiązywania przepisów autorytarnie wstrzymujących lub zawieszających bieg terminów procesowych - po odwołaniu stanu zagrożenia epidemicznego lub epidemii nastąpiłaby konieczność lawinowego wręcz podejmowania odpowiednich czynności w zakresie prowadzonych postępowań. Jednocześnie uznać należy, że decyzje wydane już w trakcie trwania stanu epidemicznego lub stanu epidemii w czasie obowiązywania art. 15zzs COVID-19U są wydane skutecznie, co nie zmienia jednak faktu, iż strony miały i w dalszym ciągu mają możliwość skorzystania z zawieszenia biegu terminów, o czym mowa w przepisach sp.fund. O ile jednak ustawodawca daje podstawy organowi do podejmowania czynności, o tyle podkreślenia wymaga to, że nie wyłącza to uprawnienia strony do skorzystania $\mathrm{z}$ instytucji zawieszenia biegu terminów, o czym stronę należy wyraźnie pouczyć.

\section{Bibliografia}

Gąsiorowski J., Ograniczenia, możliwości i funkcjonowanie sądownictwa powszechnego $i$ stałych sądów polubownych w sprawach cywilnych podczas trwania epidemii w Polsce, ADR. Arbitraż i Mediacja 2020, nr 2.

Jaśkowska M., w: Instytucje prawa administracyjnego, red. R. Hauser, Z. Niewiadomski, A. Wróbel, Warszawa 2015.

Klich A., Electronic Communication with Public Administration in the Time of COVID-19 Poland's Experience, International Journal of Environmental Research and Public Health 2021, t. 18, nr 2 (685), doi: 10.3390/ijerph18020685.

Kulski R., Wplyw stanu zagrożenia epidemicznego lub stanu epidemii ogłoszonego z powodu COVID-19 na postepowanie cywilne, Monitor Prawniczy 2020, nr 9.

Mazzucato M., From Market Fixing to Market Creating: A New Framework for Innovation Policy, Industry and Innovation 2016, t. 23. 
Ostałowski J., w: Szczególne rozwiązania wspierające realizacje programów operacyjnych w związku z wystąieniem COVID-19 w 2020 r. Komentarz, Gdańsk 2020, https://sip.lex.pl/ \#/commentary/587830858/628298?keyword=specustawa\%20wdro\%C5\%BCeniowa\&to $\mathrm{cHit}=1 \& \mathrm{~cm}=$ STOP [dostęp: $2.12 .2020 \mathrm{r}$.].

Piłat W., Komentarz do art. 15zzs COVID-19U, w: Ustawa o szczególnych rozwiązaniach zwiazanych z zapobieganiem, przeciwdziałaniem i zwalczaniem COVID-19, innych chorób zakaźnych oraz wywołanych nimi sytuacji kryzysowych. Komentarz, red. K. Szmid, 2020 [baza danych Legalis]. 
